\title{
On Chronobiology
}

\section{Section Editor}

Anne W. McCammon,

MD, FAAN
Correspondence to

Dr. Hartley:

sarah.hartley@rpc.aphp.fr
They sit alone, the lost, the blind, the broken Who cannot feel the tolling beat of time Adrift upon a vast uncharted ocean The cellular flotilla out of line

For we are made of many different drummers To each his rhythm; each his lonely beat They march together, synchronizing functions Or else run free: a metabolic feat

Our clock is set each morning on awaking As light informs the brain that it is day With interlocking loops of gene expression and delicate synaptic interplay

A gentle shift in light, a subtle lesion Night work, shift work, jet lag, modern life The clockwork stutters and from weakened signal: Insomnia, fatigue, internal strife

I diagnose the cause of moving rhythms The why of lack of exercise and light Neurological examination Melatonin levels in the night

The timeless searchers can be called to order Artificial signals for the blind For those that see, bright light and early rising To draw the lonely dancers into line. 


\title{
Neurology
}

\author{
On Chronobiology \\ Sarah Hartley \\ Neurology 2014;82;901 \\ DOI 10.1212/WNL.0000000000000193
}

\section{This information is current as of March 10, 2014}

\section{Updated Information \&} Services

\section{Subspecialty Collections}

Permissions \& Licensing

Reprints including high resolution figures, can be found at: http://n.neurology.org/content/82/10/901.full

This article, along with others on similar topics, appears in the following collection(s):

All clinical neurophysiology

http://n.neurology.org/cgi/collection/all_clinical_neurophysiology Circadian rhythm sleep disorders

http://n.neurology.org/cgi/collection/circadian_rhythm_sleep_disorders

Information about reproducing this article in parts (figures,tables) or in its entirety can be found online at:

http://www.neurology.org/about/about_the_journal\#permissions

Information about ordering reprints can be found online:

http://n.neurology.org/subscribers/advertise

Neurology ${ }^{\circledR}$ is the official journal of the American Academy of Neurology. Published continuously since 1951, it is now a weekly with 48 issues per year. Copyright (C) 2014 American Academy of Neurology. All rights reserved. Print ISSN: 0028-3878. Online ISSN: 1526-632X.

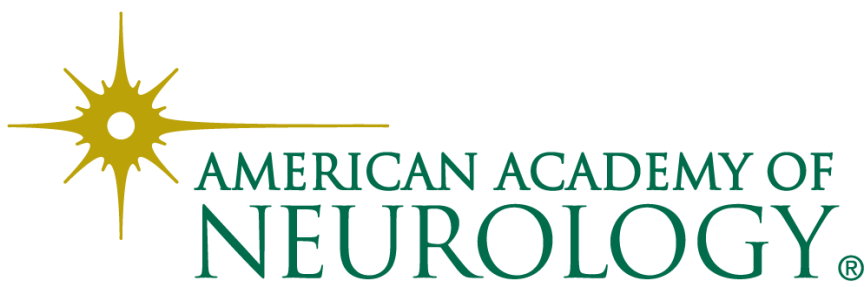

